\title{
A Partial Study of Early Iowa Newspapers
}

(The following was adapted from a paper read by the writer on December 16, 1927, before the Frontier Club of Des Moines.)

It was on May 11, 1836, that the first newspaper printed in what is now Iowa, the Dubuque Visitor, issued its first number. Iowa was then almost "without form and void." Without going back through the Spanish and French jurisdictions over this region, or the Louisiana Territory jurisdiction, Missouri Territory was given authority over it in 1812 , but in 1820 when Missouri was made a state it lost that jurisdiction, and the region was no man's land so far as civil government was concerned, but as there were almost no people here but Indians, and they had their own government, such as it was, and a few fur traders, and they didn't think they needed government, it didn't matter much for a while at least. So from 1820 until 1834 there was no civil government here. June 28,1834 , the region was attached to Michigan Territory and about two months later, or September 6, 1834, Dubuque and Des Moines counties were created, Dubuque County being the north portion down to a short distance above Davenport, and Des Moines County the southern part.

Attention was then being directed to Dubuque, particularly for two reasons, the lead mines there, and its proximity to Michigan Territory. The two-year-old town claimed 1000 people. This region was at that time a part of Michigan Territory, but the following July 3 , Wisconsin Territory was created and it became a part of that territory, and Dubuque, centrally located, on a great navigable stream, the largest town in Wisconsin Territory, had a good prospect of becoming the capital. But Burlington won over Dubuque and it was the capital of Wisconsin Territory from 1837 until Iowa Territory was created in 1838, and remained the capital of Iowa Territory until 1841, when Iowa City was made the capital.

To John King belongs the honor of establishing this first paper in the region which afterward became Iowa. He came to Dubuque in 1834, soon determined to establish a newspaper there, and the fall of 1835 returned to Olio. He secured a young man at Chillicothe, William Carey Jones, a practical printer, to accompany him. They proceeded to Cincinnati, purchased a Smith hand press, type, etc., brought them by steamboat to Dubuque, 
got another printer, Andrew Keesecker of Galena, Illinois, and on May 11, 1836, issued the first number of the Dubuque Visitor. Almost a complete file of the first year is in the Historical Department. The headline shows it published at Dubuque Lead Mines, Wisconsin Territory, May 11, 1836. The fact was the region was still Michigan Territory, but the bill had been passed creating Wisconsin Territory, but was not to go into effect until the following July 3 .

The next paper to be established in what was to be Iowa was at Montrose, the Western Adventurer and Herald of the Upper Mississippi, June 28, 1837, a little over a year after the Dubuque Visitor. Nearly a complete file of the Western Adventurer is in the Historical Department. The publisher or financial backer was Dr. Isaac Galland, who in 1829 had settled on the west side of the Mississippi River at the upper end of the rapids, at a point about midway between the present sites of Keokuk and Montrose. This man was the agent of the New York Land Co., was a physician, had established the first school taught in what afterward became Iowa, in 1830 , was a remarkable and a public spirited man. Publishing the Adventurer was largely with him a real estate enterprise. The editor was a no less remarkable man than Galland, Thomas Gregg, who had been publishing the Carthagenian at Carthage, Illinois. Montrose was just assuming its new name. No. 1 of the Adventurer says the troops had just departed and the Des Moines Land Co. had possession of the fort where a new town would soon be laid out to be called Montrose. At this time it was scarcely a village. The Adventurer was 7 columns, 4 pages, $\$ 3.00$ per year. It lived only about a year.

Later in 1837, but the exact date not known to us, was established the third paper in this region which was to be Iowa, the Territorial Gasette and Burlington Advertiser, the oldest paper in Iowa now in existence. In other words it is still running, the name having been simplified to Burlington Gazette. It was the first paper to announce its politics. It was Democratic, and remains so to this day. Its founder was James Clarke, who, eight years later became the third and last territorial governor of Iowa and whose wife was a daughter of General Henry Dodge, and a sister of Augusuts Caesar Dodge. He was a printer by trade, had published a paper at Belmont, the first capital of Wisconsin Territory, and had come to Burlington to establish the Gazette 
when the capital was removed there. The settlement where Burlington now is had been started four years before the Gazette was established, or in 1833 . When the Gazette was established it was a frontier village of only about 400 people. There were no brick buildings-only unfinished, temporary frame buildings, which we would call shacks. Stumps were still in the streets. But a large migratory movement was setting in toward the Iowa country.

In 1838 two more papers were started, the Fort Madison $P_{a-}$ triot being one, established by James G. Edwards March 24, 1838. In politics it was Whig, the fourth paper in order of establishment, and the first Whig paper. In less than a year, or in December, 1838, Edwards discontinued the paper at Fort Madison and removed the material to Burlington. The other paper of 1838 was the Iowa Sun and Davenport and Rock Island Neres, the fifth paper in the Iowa section and was started August 15, 1838, by Andrew Logan. It ran only a few years.

The year 1839 witnessed but one paper started, the Iorva Patriot at Burlington, Whig in politics, which was the sixth paper in Iowa. The year 1840 witnessed the founding of two, both at Bloomington (now Muscatine), the Iowa Standard and the Bloomington Herald. The Standard, Whig, was started October 23, 1840, by William Crum and W. D. Bailey. In April, 1841, Crum became sole owner and discontinued it at Bloomington and removed the plant to Iowa City where he soon established the Iozea City Standard, and when Dr. S. M. Ballard acquired it in 1848 he changed the name to Iowa City Republican. The second paper founded in 1840, the Bloomington Herald, was only four days behind the Standard in starting, or October 27, 1840. It was established by Thomas Hughes and John Russell, and was Democratic. In 1846 after a change of ownership, the paper was changed to Whig. The name was soon changed to the Muscatine Journal.

We have now passed over five years, 1836 to 1840 inclusive, and eight papers have been established, two being discontinued, the one by removal, the Fort Madison Patriot, and one by discontinuance, the Western Adventurer at Montrose. So we enter 1841 with only six papers in existence, but that year witnessed the founding of six new ones and the discontinuance of one and that by removal, the Bloomington Standard. One of these six 
was established at Dubuque (the Miners' Express), one at Fort Madison, one at Davenport (the Davenport Gazette), Whig, and three at Iowa City, the removal of the territorial capital being the inciting cause of these three being started. For the next five years but few papers were establishd, and about as many fell by the wayside as were started, that is from 1842 to 1846 inclusive, the period being entered with nine papers and ended with ten. In that period, in 1843 the Keosanqua. Republican was established, the first paper not in a Mississippi River town, except in Iowa City, the new capital.

Late in 1846 Iowa Territory became a state. Settlements werc pushing back farther into the interior, and the population had grown to 100,000 . Beginning with 1847 , not less than five papers were established in any one year during the period we are studying, reaching to 1860 . In 1847 five papers were established, one, the Western Democrat at Andrew, Jackson County. This was the home of Ansel Briggs, the first governor of the state. In 1849 Governor Briggs became owner of the paper, but sold it in 1852. Another paper started in 1847 was the Iowa Sentinel, a Democratic paper started at Fairfield. It only lived until 1856. But the ncw papers were creeping back into towns back of the big river.

In 1848, the year of the Taylor-Cass presidential campaign and the first one in which Iowa voters participated, six new papers were started, the Ottumwa Courier being one, and the Kanesville Fronticr Guardian being another. The Courier was Whig and the Frontier Guardian was Whig and Mormon.

The year 1849 brought five new papers, two in river towns, one at Dubuque, the Northrest Demokrat, a German paper, and one at Keokuk, the Des Moines Valley Whig, the name soon being changed to the Keokuk Gate City. Another was the Iozoa Freeman at Mount Pleasant, Anti-slavery, cdited by Samuel L. Howe, the noted educator. Another of 1849 was the Fairfield Ledger, Whig, and the other of the five of that year was at the second Fort Des Moines, the fort at the forks of the Des Moines and Raccoon rivers, the Iozea Star, Democratic, by Barlow Granger.

In 1850 eight new papers were started, in 1851 , five, in 1852, five, in 1853, six, in 1854, fifteen, in 1855, seventeen, in 1856, forty, in 1857, twenty-four, in 1858, twenty-one, in 1859, twentyone, and in 1860 , the end of the period studied, twenty-three, 
The reason for the great increase in the number founded in this ten or eleven year period, 1850 to 1860 , is the growth and rapid settlement of the state, and the increasing interest in politics. When we think of forty new papers being started in Iowa in 1856 we know that something was going on.

The population had nearly trebled during the previous five year period, having reached in 1856 nearly 518,000. The following list of counties in which new papers were started in 1856 shows their distribution (notice many are back in the interior): Appanoose 1, Boone 1, Bremer 1, Buchanan 1, Clayton 2, Clinton 1, Dallas 1, Davis 1, Dubuque 2, Fayette 1, Floyd 1, Guthrie 2, Hardin 1, Iowa 1, Jackson 2, Jasper 1, Jones 1, Keokuk Co. 1, Linn 1, Lonisa 1, Madison 1, Marion 1, Mills 3, Mitchell 1, Polk 1, Poweshiek 1, Scott 5, Tama 1, Washington 1, Wayne 1. Of these 40 papers 7 were neutral politically, 16 were Democratic and 17 were Republican.

During the whole twenty-five year period of our study, 1836 to 1860 , inclusive, 222 papers were established, 118 were discontinued, and 104 remained running. At the end of this year, 1860 , Iowa's population was about 675,000 . With 104 papers in existence means one paper to each 6,500 , which was surely a plenty when we consider that at that time only one-fifth of the population lived in the cities and towns, and that the remaining four-fifths were scattered in farm homes, a large portion in remote locations where if they had mails even once or twice a week they were lucky. Then as the publisher got but little advertising and had to rely more on subscriptions, having to charge $\$ 3.00$ per year for them, and as $\$ 3.00$ then meant a lot of money, it is a wonder that so nearly one half of the papers that were started continued to live.

It was so easy to induce an ambitious young man to start a paper! Many of these were started in towns that along with the papers started there have long since passed into the limbo of oblivion. Witness the Calhoun (Harrison County) Flag, the New Oregon (Howard County) Sentinel, the Lancaster (Keokuk County) Western Friend, the Simoda (Shelby County) Nezes Idea, the Preparation (Monona County) Zion's Harbinger, the Ellington (Hancock County) Sentinel, the Bradford (Chickasaw County) Cedar Valley News, and many others.

It is hard at this time to realize what an important part poli= 
tics had in the newspaper business during that period. Waves of political feeling and excitement surged back and forth throughout the new territory and state. The slavery question, the Mexican War, the repeal of the Missouri Compromise, the Fugitive Slave Law, the organization of the Republican party, these and kindred subjects were enough to excite the spirit of party strife to fever heat.

As was demonstrated by Prof. Herriott a few years ago, and rather to the surprise of most of us, Iowa was largely settled at the first by Southerners, or by families whose parents were Southerners. Men of Southern birth predominated among the public servants of the territory and of the new state. Of course all Northerners were not Whigs, nor were all Southerners Democrats, but generally so, and it came about that in territorial times the Democrats exceeded the Whigs in numbers, as they also did for a few years after it became a state.

Knowing that the majority was with the Democratic party one would suppose the Democratic papers were more numerous than the Whig papers. The first two papers, the Dubuque Visitor, 1836, and the Montrose Adventurer, 1837, were nominally independent, although the former had Democratic leanings, and the latter a preference for the Whigs. By 1840, when there were six papers, two were Whig, two Democratic, and two independent. In 1846 when there were ten papers, five were Whig and five Democratic. In 1848 when the number had increased to twenty, ten were Whig and ten Democratic. Two years later, or 1850, there were twenty-nine papers, fifteen wore Whig, thirteen Democratic and one independent. In 1854 when James W. Grimes wrested the governorship from the Democrats, there were fortynine papers, only sixteen Whigs, twenty-two Democratic, and eleven independent or neutral. Whig partyism at this time was somewhat disintegrating. Grimes' personality and the increasing dislike of slavery among the new Iowans were big factors in the result. In 1860 with one hundred and four papers in the state, fifty-nine were Republican, thirty-five Democratic, and ten independent or neutral.

It appears that in the early part of this period the Whigs were clearly in the minority, but maintained as many papers as the Democrats, and that when the time came that the Republicans attained to about the same proportionate majority the Demo- 
crats had previously enjoyed, then the Republican press far outnumbered the Democratic press.

From the figures here given it is shown that there was a larger number of independent or neutral papers along early in the fifties than previously, or than a few years later. County seat fights, the ambition of a village to be a county seat, the opening of a new county and the desire for the profits of publishing the delinquent tax lists, and the waning power of the Whig party, all contributed to cause many publishers to take no stand politically.

We marvel now at the large number of papers established. There were many things contributing to this urge. Among them we may mention real estate boomers, county seat ambitions, the rivalries of towns other than aspirants for county seats-business rivalries, political rivalries, and party rivalries. As an example of party rivalry, take the new county seat town of Boonesboro, Boone County. In 1856 their first paper was established, the Boone County Nezes, a Republican paper. But the Democrats must have an organ, so the next year, 1857, the Boone County Democrat was born. But it only lived two years, dying in 1859 . But Boone County must have a Democratic paper, so next year another Democratic paper was started, the Boone County Herald. I't, however, was suspended before the end of the Civil War, as also was the Republican paper. The situation there was duplicated in many other counties.

As an example of factional rivalries within the party: In 1850 Burlington had two able papers, the Gazette, Democratic, and the Hazkeye, Whig. A rival faction of Whigs caused James M. Morgan and others to start the Burlington Telegraph. It ran for five years, and was then absorbed by the Hazkeye. This situation also was duplicated in many other counties.

But Dubuque County furnished an example of party, of factional and of business rivalries that perhaps excelled any other place in the new state. Starting in 1836 with one paper, the first in the Iowa region, it was never without one. By 1841 it had two. In 1846 for one year it dropped back to only one. But in 1847 it had two, in 1848 it had three, in 1849 it had four., in 1851 it had five, in 1856,1857 and 1858 it had seven, and 1859 it had eight. In August, 1857, when it had seven papers, six of them were dailies, Times, Tribune, Express and Herald, Repub- 
lican, Northreest, and Demolrat, the last German. At this time there were 3,939 families in Dubuque, population perhaps 15,000. In the twenty-five year period studied, Dubuque had established fifteen papers, but came out at the end of 1860 with but five. Scott County in that period had established sixteen papers and at the end of 1860 had but three.

The kinds and qualities of the men who established these frontier papers and printing offices were of course various. Some were men who had been schooled at the case, and to whom the smell of printers' ink was pleasant to their nostrils. Some were men who knew nothing of the art of the printer, but who saw, or thought they saw, the big influence a paper would have in business or in polities, and were willing to invest their money or their labor in founding it. Some were men of liberal education, acquired in the schools, some were men who had absorbed a fair amount of knowledge in the school of life, some had picked up much education from the articles they had sct up at the printers' case, and who had by the interest thus awakened, pursued the general reading of literature. Some were men who knew the mechanics of the press and the types, but to whom grammatical construction was an unknown art.

Among the men of that period who by their ability added distinction to the newspaper profession were James G. Edwards, Clark Dunham, and Fitz Henry Warren of the Burlington Hazkeye, D. A. Mahoney of the Dubuque Herald, John Mahin of the Muscatine Journal, D. M. Richardson of the Davenport Democrat, S. M. Ballard of the Iowa City Republican, W. W. Junkin of the Fairfield Ledger, James B. Howell of the Keoluk Gate City, A. B. F. Hildreth of the Charles City Intelligencer, and Charles Aldrich of the Webster City Freeman. There were scores and scores of others now almost lost to fame who had equal ability and filled their niches equally well, exercising an influence nearly always for good educationally and morally. I speak more particularly of the one we call the country editor, or editor of a weekly paper in a small town or in a county seat of a rural county. His position was unique and his opportunities for usefulness was limited only by his ability and character. Not only was he the recorder and purveyor of local news from town and country, but he was a part of every public movement. If he had wisdom 
and grace, no one could excel him in directing public opinion or policies.

There are romances in connection with the establishment of many of the Iowa papers, at least they seem to us as romances, though to those struggling, ambitious men they were rough and cruel reality. A large number of the presses and materials were brought by ox teams to the new towns where the papers were established. William M. Stone brought in 1855 by ox team the press and materials from Keokuk to Knoxville to start the Journal. So did William Crum haul in 1841 the press from Bloomington to Iowa City to start what afterward became the Iowa City Republican. So did Jesse M. Shepherd in 1843 haul the press from Keokuk to Keosauqua to start the Iowa Democrat at that place. So did James Iler in 1856 haul from the east the press to Winterset that was used in starting what afterward became the Madisonian, and so it was in many, many other cases. Many of us know of our own knowledge how slow the oxen were, how soft and miry the prairie sloughs were, and what were the privations of frontier living.

I have said that in 1860 with 104 newspapers and 675,000 population, that meant one paper to each 6,500 people. As Iowa became more thickly populated, as the rivalries between small towns increased, as the evolution of the new state progressed, newspapers became more numerous. I have not had the time to pursue the study sufficiently to find when the greatest number of newspapers existed in Iowa, but they are now decreasing. Twenty years ago, 1907, there were 934 newspapers in the state. That is not counting church, religious, educational, nor trade papers. That makes one paper to 2,366 people. Ten years later, or ten years ago, 1917, there were 806 papers, or one to 2,925 population. Now, 1927, there are 565 papers, or were early in the year, or one paper to 4,283 population. In other words, with a slow but gradual increase of population during the last twenty years, the number of newspapers has decreased from 934 to 565, and the end is not yet. Scarcely a week goes by but brings a consolidation or two, or a discontinuance, and seldom the establishment of a new one. The reasons are both economic and political. Even the country newspaper of today is very different mechanically and economically from the pioneer days. Politically, too, there is but little demand for the partisan paper. The intensity 
of feeling that swept the emotions of the people before and during the Civil War, and caused party lines to be so tightly drawn, no longer exists. There is no longer party discussion in the papers today even as there was thirty, or twenty years ago. We have left the Civil War and slavery too far behind to bring forward the old divisions and maintain them. Now it is good roads, or farm relief, or reduction of taxes or something economic that seems most to stir our hearts. So we are bidding a fond and regretful farewell to the pioneer newspaper man, to him who used to fire and feed our interest in public matters. It may be just as well. But the editorial page in most of the Iowa papers is surely shorn of its old glamour. For instance, when the two papers at Marengo, one Republican and the other Democratic, consolidated, the new publication necessarily became independent politically, and the snap and spice of old party rivalry departed from the printed page. So it is with the Dubuque Herald, that valorous old Democratic paper, since it took over the TimesJournal, its Republican contemporary. So it is with the Cedar Rapids Gazette since it took over the Cedar Rapids Republican. So it is with dozens of other papers. They now often furnish very interesting editorials on the beauties of the Iowa seasons. It is doubtless well that it is so, but it has taken out part of the joy of life for some old partisans. But times have changed. This is a new era and the newspapers are being adapted to public welfare, to civic improvement, to the conditions of local society, to education, and to a greater variety of subjects than were the old papers. Many of them, however, now make little or no editorial comment, but those that do, many of them are of high character. With a lessening of numbers, the remaining papers, many of them, are successful financial enterprises, and are largely directed on lines of progressive business. The standard of work on both the country and city papers has greatly improved even within the last decade. More educated young men are entering the newspaper field, and the ethics of the profession is greatly improved, both among city reporters and country writers. We are living in a new age and it is better than the old one.

Table showing the number of newspapers established in Iowa each year from 1836 to 1860 inclusive, the number discontinued each year, and the number in existence at the end of each year. 


\begin{tabular}{|c|c|c|c|c|c|c|c|}
\hline '36 & '37 & '38 & '39 & 30 & '4.1 & '42 & '43 \\
\hline Established ……....... 1 & 2 & 2 & 1 & 2 & 6 & 1 & 2 \\
\hline Discontinued & & 2 & & & 1 & 3 & 1 \\
\hline In Existence .......... 1 & 3 & 3 & 4 & 6 & 11 & 9 & 10 \\
\hline '45 & $' 46$ & $' 47$ & '48 & ${ }^{\prime} 49$ & '50 & 31 & ${ }^{\prime} 52$ \\
\hline Established ….......... 1 & 2 & 5 & 6 & 5 & 7 & 6 & 5 \\
\hline Discontinued & 1 & 1 & & 2 & 1 & 2 & 5 \\
\hline In Existence .......... 9 & 10 & 14 & 20 & 23 & 29 & 33 & 33 \\
\hline '54. & '55 & $' 56$ & 57 & ${ }^{\prime} 58$ & ${ }^{\prime} 59$ & '60 & \\
\hline 15 & 16 & 41 & 24 & 20 & 22 & 23 & \\
\hline$\ldots . . . . . .4$ & 0 & 15 & 11 & 17 & 19 & 20 & \\
\hline Existence ............ 49 & 56 & 82 & 95 & 98 & 101 & 104 & \\
\hline
\end{tabular}

Total 222

'Total 118

Total 104

Papers established before the Civil War and still running, arranged chronologically as to the dates of establishment.

Burlington Gazette (began as Territorial Gazette and Bur-

- lington Advertiser) .1837

Burlington Hawkeye (began as Iowa Patriot) June 6,1839

Muscatine Journal (began as Bloomington Herald) ....... October 27, 1840 Iowa City Press-Citizen (began as Iowa Capital Reporter)_.Dec. 4, 1841 Ottumwa Courier (began as Des Moines Courier)............... August 8, 1848 [Keokuk] Daily Gate City (began as Des Moines Valley Whig and Keokuk Register). March, 1849

Fairfield Ledger (began as Weekly Ledger)........................... November, 1849 Oskaloosa Herald (began as Iowa Herald). July 1,1850

[Dubuque] Telegraph-Herald (began as Dubuque Herald) April 19, 1851 Tipton Advertiser (began as Cedar County Advertiser)........Nov. 12, 1858 [Maquoketa] Jackson Sentinel (began as Maquoketa Sentinel) May 25, 1854

Keosauqua Republican (began as Keosauqua Republican)Sept. 12, 1854. Independence Conservative (began as Independence Civilian) May 17, 1855

Davenport Democrat (began as Iowa State Democrat)...October 15, 1855 Decorah Republican (began as Decorah Chronicle) October, 1855

Knoxville Journal (began as Knoxville Journal) October, 1855

Marshalltown Times-Republican (began as [Lafayette] Central Journal). ...November, 1855

Clinton Advertiser (began as Lyons Advocate) 1855

Des Moines Register (began as Iowa Citizen) February, 1856

[Waverly] Independent Republican (began as Waverly Republican) March 5, 1856

Maquoketa Excelsior (began as Maquoketa Weekly Excelsior) 
Charles City Intelligencer (began as St. Charles Republican

Intelligencer) July 31,1856

Anamosa Eureka (began as Anamosa Eureka). August, 1856

Dubuque National Demokrat (began as National Demokrat)...Aug., 1856 [Marengo] Pioneer-Republican (began as Iowa Visitor).........Sep. 6, 1850 [McGregor] North Iowa Times (began as North Iowa 'Times) October 10, 1850

Witerset Madisonian (began as Iowa Pilot).......................November 6, 1856

Clinton Herald (began as Clinton Herald) ........................ December 18, 1856

Montezuma Republican (began as Montezurna Republican) .....................1856

Indianola Herald (began as Weekly Iowa Visitor)................ pril 2, 1857

Council Bluffs Nonpareil (began as Council Bluffs Nonpareii) May 2, 1857

[Webster City] Daily Freeman-Tribune (began as Hamilton Freeman)

June 26,1857

Chariton Herald-Patriot (began as Chariton Patriot) 1857

Waterloo Evening Courier (began as Waterloo Courier)......Jan. 18, 1859

Clarinda Herald (began as Page County Herald)...........................

Osceola Sentinel (began as Osceola Courier) .................................July 30, 1859

Cresco Plain Dealer (began as New Oregon Plain Dealer) 1859

Wapello Republican (began as Wapello Republican) .1859

[Sigourney] Keokuk County News (began as Keokuk County News) 1860

\section{THE FIRST MORMON PRESS}

The Indianola Journal office has the first press the Mormons ever owned. It was pitched into the Mississippi at the time of the Nauvoo war, but was afterwards fished out, and is now used to print one of the best local papers in all Christendom. It is a No. 6 Washington press; and Brady proposes to sell it to Brigham Young for five thousand dollars. We don't think old Brig will invest. A man with eighty-five wives can get pressed cheaper!-From the Des Moines Daily State Register, January 10, 1869. (In the Newspaper Division of the Historical, Memorial and Art Department of Iowa.) 
Copyright of Annals of Iowa is the property of State of Iowa, by \& through the State Historical Society of Iowa and its content may not be copied or emailed to multiple sites or posted to a listserv without the copyright holder's express written permission. However, users may print, download, or email articles for individual use. 